\title{
The neoliberal location of asylum
}

\author{
Paolo Novak \\ pn4@soas.ac.uk
}

\section{This is the accepted version of the article, forthcoming in Political Geography - JPGQ_1978}

\section{Keywords}

\author{
borders; EU border management; neoliberalism; asylum seekers; spaces of law
}

\begin{abstract}
What can be learned about the European migration crisis by studying it at its margins? Framed by this question and premised on evidence collected during four months of field research in a central Italian province, the paper investigates the governance transformations engendered by the migration crisis through a study of the Extraordinary Reception Centres (CAS) set up by the Italian government to host asylum seekers across its territory. The paper builds upon Dikeç's (2009) conceptualisation of the "where" of asylum to map their legal and geographical location within the EU border regime, and engages with current debates on EU borders a) to highlight the centrality of marginal locations such as Macerata to the functioning of the EU border regime, arguing that CAS are central to such regime as they confirm its humanitarian pretences b) to intervene on debates concerned with the spatiality of EU borders, arguing that greater analytical attention should be given to their territorial configurations c) to evidence the neoliberal character of the governance transformations engendered by the crisis, beyond their migration management function. Border management is an engine of state transformation. The paper highlights the all-pervasiveness of neoliberalism in this process and the weakening of democratic accountability that accompanies it. It suggests, on these bases, that what can be learned about the European migration crisis by studying it at its margins, is that the governance transformations it has engendered invest migrants and non-migrants alike, offering two reflections in this respect.
\end{abstract}

\section{Introduction}

In many respects, the Macerata province of the Marche Region of Italy, the empirical setting of this article, could not be more peripheral to the ongoing migration crisis in Europe. The nearby port of Ancona has ceased to be one of the main entry points for Afghans, Pakistanis and Syrians arriving from Greece. There are no large squats or irregular settlements as in other parts of Italy and Europe. There are no clashes between migrants, activists and the police, such as those witnessed in Ventimiglia, at the Italy-France border. There is no overt and over-exploitation of the migrant labour force, including asylum seekers, akin to that observable in the fruit picking fields of northwest Italy, or in the tomato growing areas of the south.

The 922 Nigerian, Pakistani, Bangladeshi, Gambian, and others, asylum seekers hosted in Macerata Province ${ }^{1}$ certainly do not experience the crisis in the same way as migrants in 
Bihac or Lesvos, or even fellow asylum seekers in reception centres in other parts of Italy. Rather, most commonly, after being offloaded from one of the boats involved in so-called Search and Rescue (SAR, henceforth) operations across the Mediterranean and spending some time in an identification centre, they enter the province in small groups, by bus, with local authorities informed in advance of their arrival. Once there, they benefit from a seemingly efficient and effective system of protection, whereby six accredited organisations work in coordination with the Prefettura (the provincially-decentralised office of the Interior Ministry) to house them in 65 mostly small reception centres across the province, and to offer them vocational training, cash and other allowances. As a seemingly "good" place to be an asylum seeker, the Macerata province seems indeed marginal to the crisis.

Yet, even if some of the key forces and relations associated to such crisis are attenuated and less visible, their essential traits reverberate across the province, making Macerata an interesting vantage point to examine the crisis. Despite asylum seekers' numbers being in line with the average recommended by the Government ( 2.5 per thousand citizens), their presence is perceived to be excessive by many. Some local administrations have refused to host them, accentuating tensions between national administrative levels, with region, provinces and municipalities often at odds with each other and with the central government over the (al)location and presence of asylum seekers, in ways that resemble the disputes among European member states. The economic crisis has further reduced the possibility of employment for everyone, and asylum seekers most often sit idle in the hotels and apartments that host them. Far right political groups are on the surge and episodes of racist violence are on the increase. Indeed, soon after the end of the field research informing this paper, news about an Italian man shooting indiscriminately at "black people" turned the spotlight on what had been considered, until then, a tranquil province and a relatively good example of asylum management, accentuating these latent tensions, and generating profound transformations in the way in which asylum seekers are managed in the province.

What can be learned about the European migration crisis by studying it at its margins?

At its broadest, the paper is informed by this question. It deploys the term crisis not to corroborate the by now discredited (Lindley, 2014; Mezzadra, 2015) narrative designating as a "crisis" the arrival in Europe of over four million asylum seekers since $2011^{2}$, but rather to indicate an analytical direction: that of taking "note of the effects of the claim to crisis" (Roitman, 2013: 12; Dines et al., 2018). Specifically, the paper is concerned with the governance transformations engendered by such claim and, in turn, with their character. The paper examines these transformations from a relatively peripheral place like Macerata, in the conviction that Europe's margins are key sites of investigation for analysing the "contested geographies" that these transformations engender (Painter et al., 2017: 260).

On these bases, the paper develops an answer to the above question by taking as its object of analysis and investigation the Extraordinary Reception Centres (Centri Accoglienza Straordinaria, or CAS henceforth) set up in Macerata province to host asylum seekers, and by empirically mapping their location within the EU border regime and its governance. This mapping exercise is framed by Dikeç's (2009) conceptualisation of the "where" of asylum, which he defines in relation to both the "legal spaces" (ibid: 183) and the "geographical location" (ibid: 188) where asylum takes place. It engages with contemporary debates on EU borders to a) highlight the centrality of marginal locations such as Macerata to the functioning of the EU border regime b) to intervene on debates concerned with the spatiality of EU borders and c) to evidence the neoliberal character of the governance transformations engendered by the crisis, beyond their migration management function. 
First, this mapping exercise expands literature on the humanitarian governance of EU borders, by focusing on asylum reception. The humanitarian reason (Fassin, 2012) increasingly deployed to manage undesirable populations (Agier, 2012) configures a dialectic of care and control (Pallister Wilkins, 2015) in which asylum is not just integral, but crucial to the governance of EU borders (Tsianos and Karakayali, 2010; Hess and Kasparek, 2017; Pinelli, 2017). Indeed, spaces of care are dialectically related to the exclusionary dimensions of the humanitarian border, as they jointly configure its governance (Williams, 2015). Yet asylum reception remains understudied (Cuttitta, 2017) in a field mostly concerned with exclusionary (e.g. detention facilities, see Mainwaring and Silverman, 2017) or filtering (e.g. hotspots, see Tazzioli, 2017) facilities, with the reassertion of "internal" EU borders (Lendaro, 2016), or with migrants' autonomous trajectories within Europe (Davies et al., 2017). Heeding Walters' (2011) exhortation to undertake a fuller mapping of the humanitarian border, the paper expands this literature studying instead an institution (CAS) and a location (Macerata) where asylum takes place (at least in the meaning conferred to it by Italian law) rather than being denied. It shows that while CAS in Macerata may occupy a marginal position within a regime that is intent in dispersing and forcibly relocating migrants (Garelli and Tazzioli, 2018) or in denying them their right to seek asylum (Moreno Lax, 2017), they are deeply integrated within it. Indeed, the paper argues that CAS are a central $\operatorname{cog}$ in the governance transformations engendered by the EU border regime as they provide a (legal and geographical) location where to warehouse asylum seekers, confirming the regime's humanitarian pretences.

Second, through this mapping exercise the paper intervenes in the debate about the spatialities of EU borders, arguing that greater awareness should be given to their territorial manifestations. Over the last decade and a half, contributions dissecting the spatiality of EU borders have convincingly captured the unprecedented process of externalisation (de Genova, 2017; Andersson, 2014; Vives, 2017) that renders them mobile and itinerant (Casas Cortes et al., 2015). Detailing instead the extent to which the humanitarian management of EU borders generates governance transformations at national, regional, provincial and municipal levels, the paper builds upon these contributions, yet it underscores the centrality of linearly-defined national and sub-national jurisdictions. The spatiality of EU borders, it will be argued, is defined by both sets of dynamics -those that render them mobile and those that reinforce their linear inscription (Novak, 2017).

Third, the paper points to the neoliberal character of the governance transformations engendered by the humanitarian management of EU borders. This character is evident in relation to the privatisation of reception functions (Darling, 2016) and the paper will highlight the significance of non-state contractors in defining the location of CAS. More fundamentally, however, this character is evident in relation to the governance mechanisms that define the location of CAS. Such mechanisms attempt to establish decentralised (Darling, 2016) lean and efficiency-driven decision-making processes (Rondinelli and Cheema, 2003) that weaken public scrutiny (Bruf, 2017), that mobilise political threats to extend their reach across sub-national administrative jurisdictions (Allen and Cochrane, 2010), and that are variegated in their local configurations and effects (Peck and Tickell, 2002). Neoliberalism does not reduce, but rather transforms state intervention (Fine and Saad-Filho, 2017; see also Marois and Pradella, 2015).

The paper argues that border management is an engine of state transformation. Its workings are not only dedicated to the neoliberal government of human mobility (de Genova, 2017), but also to the restructuring of the EU's governance architecture and to the reconfiguration of member states' institutional apparatuses along neoliberal lines. Highlighting the allpervasiveness of neoliberalism, the paper evidences the weakening of democratic 
accountability associated to the governance transformations engendered by the crisis. It suggests, on these bases, that what can be learned about the European migration crisis by studying it at its margins, is that these transformations do not exclusively invest migrants, but rather migrants and non-migrants alike, offering two reflections in this respect.

The paper pursues these arguments by mapping the location of CAS in Macerata province in three substantive sections. Following Dikeç's (2009), Section 2 identifies the instruments that define the legal location of CAS within Italian law, while the following two sections map the geographical location of CAS within Macerata province. Section 3 is concerned with the centrally-orchestrated allocation mechanisms that regulate the intake of asylum seekers into Macerata, i.e. the demand for CAS in Macerata; Section 4 is concerned with the contestations, refusals, and co-optations that shape the supply of CAS across Macerata province, and, in turn, their exact geographical location. The final section sketches the many transformations that have taken place in Macerata since the summer of 2017 and returns to the points made here.

The paper draws from two bouts of field research conducted in the Macerata province in 2016 and 2017 (one and three months respectively). The first bout was concerned with identifying the most significant research questions emerging from that setting, amongst which location was a crucial one. The second one was concerned with interviewing relevant government officials and NGO workers managing the reception system, visiting CAS and engaging in daily discussions with asylum seekers hosted therein through focus groups or individually, conducting participant observation in sites such as police offices, bus stations, mobile phones and food shops, gardens and squares in Macerata. Overall, I conducted over 50 interviews, visited 26 such centres, most of them several times, and collected copious notes of my visits, encounters and exchanges, all of which inform the following pages. At the time of writing (July 2018), I have returned to Macerata for a brief research follow-up, which informs the last section.

\section{The legal location of CAS}

"Either you shut the border, or you need to put them somewhere". This is what the Social Services Director of the Macerata Prefettura told me, when I asked her about the opposition mounted by some municipal administrations in the territory under her jurisdiction to the arrival of asylum seekers in what they considered as their jurisdiction. No doubt the then Minister of Interior was actively engaged in the first part of the equation -the shutting of borders. Over the summer of 2017, Marco Minniti travelled to Libya to foster arrangements with the internationally recognised government and with other less-formally recognised groups in the Sahel region, with the objective of disrupting the routes that had taken over 600thousand asylum seekers to Italian shores since $2011^{3}$. By engaging with the second part of the equation, however, she was pointing to one of the EU border regime's latent tensions.

As many have argued (see above), the externalisation of border controls, opaque arrangements with third countries, and the military policing of the Mediterranean are only one dimension of such regime. The latter is not only concerned with the attempt to prevent migrants' arrival, but it also ostensibly performs humanitarian functions through the reception of asylum seekers, in a dialectic of care and control that not only excludes, but also includes migrants in subordinate ways. Until the border is effectively shut, or until the violence of border management ceases to be couched in and sustained by humanitarian narratives of 
inclusion for "real" asylum seekers, migrants who reach European shores need to be located somewhere. But where?

This section is concerned with the legal location of CAS, which are instituted in law by Decreto Legislativo 142/2015 (Legislative Decree, or D.Lgs henceforth). The latter, however, draws from and is sustained by multi-level sources of law. An excursus on the evolution of the legal instruments defining CAS is thus necessary to comprehend their legal location

(Fig.1 provides a summary of the main legal instruments cited in this section).

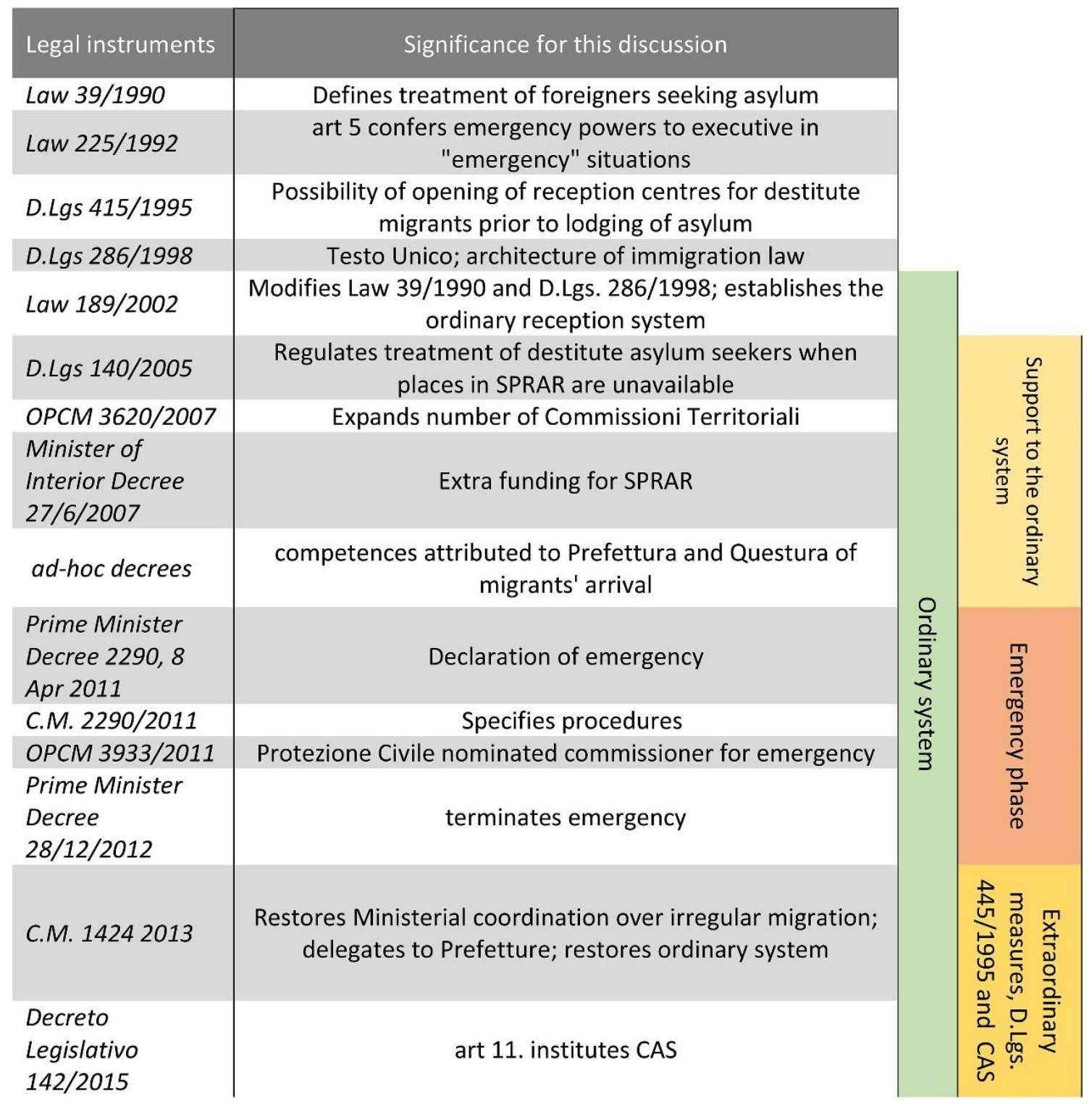

D.Lgs 142/2015 incorporates into Italian law the EU directive 2013/33/EU laying down minimum standards for the reception of asylum seekers, abrogates D.Lgs 140/2005 incorporating the previous EU Directive 2003/9/EU, and introduces a series of innovations. The most important one, for the purposes of this article, is the institution of CAS, which formalises the inadequacy of the reception system defined by Law 189/2002. 
Law 189/2002 defined the "ordinary" reception system by modifying two previous laws concerned with the treatment of non-EU immigrants. First, it intervened on the dicta contained in D.Lgs 286/1998 (the Testo Unico, or Consolidated Law). The latter disciplined immigration and defined norms regarding the treatment of non-EU citizens and stateless persons. It was not directly concerned with asylum, yet it defined an architecture that remains valid to this day: it introduced the distinction between immigrants and asylum seekers; it instituted detention centres for specific categories of migrants; it instituted the permesso di soggiorno di carattere umanitario (residence permit for reasons of humanitarian protection), which is a national protection status, complementing two other forms of protection recognised at European level (i.e. refugee status and subsidiary protection ${ }^{4}$ ). Law 189/2002 confirmed this architecture, while it modified the Testo Unico in a restrictive sense, for instance by reducing the maximum length of work-related residence permits to two years (art.5).

Second, Law 189/2002 introduced procedural changes to Law 39/1990, which was more directly concerned with asylum procedures. It abrogated several commas from the latter's art.1 (on "refugees") and substituted them with a series of dispositions. Concerned with the instrumental use of asylum claims to gain access to Italian soil, Law 189/2002 distinguished between a simplified and an ordinary procedure for the adjudication of asylum claims. The former is applied to those that are in detention, and the law expands the range of cases where this may be required (art.32 1-bis). The latter is applied to all other cases, with Art. 31 specifying that asylum claims are to be registered at the Questura (the provinciallydecentralised office of the National Police), who then issues a residence permit to the asylum seeker until her claim is assessed.

Furthermore, Law 189/2002 decentralised the adjudication of such claim to Commissioni Territoriali, an administrative body to be instituted by a Minister of Interior's Decree. Prime Minister's Decree 303/2004 provides the Regolamento Attuativo (implementation rules) for the Commissioni, instituting seven of them, and granting the Minister of Interior the authority to open and close further ones. The Law also sets temporal limits to their operations. Commissioni must grant an interview to the asylum seeker within 15 days (simplified procedure, art. 32 1-ter comma 2) or 30 days (ordinary procedure, 1-quater comma 2), and have three further days to adjudicate on her claim ${ }^{5}$.

Law 189/2002, finally, instituted the Sistema di Protezione per Richiedenti Asilo e Rifugiati (Protection System for Asylum Seekers and Refugees, or SPRAR henceforth), a network of reception facilities led by local administrations (municipalities), geared towards the integration of asylum seekers and refugees within the national territory and the provision of social services. SPRAR can and should be accessed by those following the ordinary procedure (art. 321 -sexies), if considered in destitute conditions.

The "ordinary" reception system for asylum seekers defined by Law 189/2002 is thus configured over two tiers. After an initial phase, which includes the lodging of an asylum claim and the issuance of a resident permit until the claim is resolved, the asylum seeker that is recognised as destitute by the Prefettura can access the full benefits of the reception system, subject to the availability of places in SPRAR, until the asylum claim is resolved.

Such "ordinary" system was not able to withstand the force of migration. While between 1997 and 2010 an average of 23 thousand asylum seekers arrived in Italy through irregular means, in 2008 the number stood at over 42 thousand, in 2011 at over 60 thousand, and between 2014 and 2016 estimated arrivals exceeded 150 thousand per year ${ }^{6}$. On one side, the Commissioni Territoriali did not have the capacity to process claims within the time limits set by law. On the other side, the SPRAR network never had enough places to accommodate 
such numbers. Their capacity stood at 7.823 in 2012, and it increased to only 34.039 by 2016 (SPRAR, 2017). To deal with this situation a series of measures were taken by the government.

\section{Fig.1 around here}

D.Lgs 140/2005 (art. 6) confirmed that the certification of destitution should be sufficient condition to grant the asylum seeker access to SPRAR, but asserted that when places are unavailable, s/he should be hosted in first-tier identification centres, or, if places are unavailable there, the Prefettura should directly provide a subsistence contribution. It also envisaged a reception trajectory for asylum seekers that may take place prior to the registration of an asylum claim on the part of the migrant. Such trajectory would be governed by D.Lgs 451/1995, which authorised the military policing of the Apulian maritime border, and sanctioned, in situations of emergency connected to such operations, the establishment of three reception centres for destitute migrants in Apulia. The decree, however, also envisioned the opening of reception centres in other areas of Italy, where required, specifying that these centres can be instituted by Ministry of Interior decree, in accordance with the Treasury, but without the need to consult the Council of State, the body that ensures the legality of public administration in Italy. This reception trajectory was deployed in places like Macerata and later confirmed in the D.Lgs instituting CAS (see below).

In the following years, the "ordinary" system continued to be under pressure. To prop it up the Ordinanza del Presidente del Consiglio dei Ministri 3620/2007 (a Prime Ministerial Ordinance, or OPCM henceforth; an administrative act with normative force) expanded the number of Commissioni Territoriali, while the Minister of Interior Decree of 27 June 2007 secured extra funding for local administrations engaged in SPRAR reception activities. In 2009 and 2010, the relatively contained number of arrivals meant that the phenomenon could be managed through a series of ad-hoc Ministerial Decrees attributing specific competences to the Prefettura and Questura in the jurisdiction of migrants' arrival $^{7}$. What came to be known as the "Arab Spring" and the consequent arrival of several thousand migrants to Italian shores in 2011 profoundly altered the system.

Prime Minister Decree of 12 February 2011 declared "the status of humanitarian emergency in relation to the territories of North Africa". The decree marks the beginning of a new "emergency" phase in the reception system. This phase is marked, first, by changes in the procedures for the adjudication of protection status. Prime Minister's Decree of 5 April 2011 granted prima facie temporary protection status to all those who arrived from North Africa between 1 January and 5 April 2011, in the form of 6-months resident permits. This was complemented by Circolare Ministeriale (Ministerial Circular Order) 2290/2011, issued by the Ministry of Interior, which specified the correct procedure to implement the Prime Minister's Decree. For instance, it specified that temporary protection status grants the right to travel across the Schengen area and that the residence permits to be issued should conform to EU Regulation 1030/2002. It also waved some of the documentation requirements to ascertain the nationality and identity of asylum seekers.

Second, this phase is marked by the designation of a new coordinating authority. OPCM 3933/2011 nominated the head of the Protezione Civile (a national agency under the direct authority of the Prime Minister's Office) as the Commissioner in charge of dealing with the migration crisis. The agency was tasked with coordinating the activities of relevant ministries and local administrations, primarily at the Regional level, managed the budget dedicated to 
the emergency, and could issue its own decrees (under the authority of the Prime Minister). A flurry of decrees, memos, and ordinances regulate the response to the "emergency" during the following years ${ }^{8}$. Their purpose was to extend temporary protection statuses beyond the original six months, to detail and clarify operational and procedural matters, and to allocate funds needed to face the crisis (about twenty OPCMs concerned with expenditures were issued between February 2011 and April 2013 ${ }^{9}$ ). During 2012 the number of arrivals subsided compared to 2011, and Prime Minister Decree of 28 December 2012, issued by the then head of the Protezione Civile, "terminated" the emergency.

The closure of the emergency phase meant that the overall coordination over asylum reception issues was restored under the Ministry of Interior. Circolare Ministeriale $1424 / 2013$, issued by the latter following a national coordination table with relevant national and sub-national administrative authorities, confirmed the end of the emergency phase, delegated its own Prefetture as the main operational body for asylum issues, and identified exit trajectories for the beneficiaries of temporary protection, primarily through voluntary repatriation programmes under the auspices of the IOM. Additionally, it granted each of those beneficiaries the sum of $€ 500$ and a travel document. The Circolare also effectively restored the "ordinary" system for asylum seekers' reception, based on a first reception phase followed by SPRAR for those deemed destitute. Noting, however, that some municipalities had not honoured the commitment to host asylum seekers through the SPRAR network, it invited them to comply with the nationally agreed allocation plan (an initial indication of the tensions to be detailed in the next sections).

Asylum seekers continued to arrive during this period, and some Prefetture engaged in ad hoc arrangements to obviate the unavailability of places in SPRAR. They were driven by factors such as availability of reception structures and cooperating NGOs. They were governed by the dicta contained in D.Lgs 451/1995. This was the case of Macerata (interviews with Prefettura and with Vice President of one NGO contractor). At the height of what is known as the "migration crisis" of 2015, the D.Lgs 142/2015 instituting CAS and mentioned at the beginning of this section formalises the inadequacy of Law 189/2002.

The Decree institutes extraordinary reception centres (CAS), a third tier in the "ordinary" system. Art.11 (comma 1) re-states the Ministry's commitment to the ordinary two-tier system, but sanctions that, in case of unavailability of places in the SPRAR network, or in centres opened according to D.Lgs 451/1995, Prefetture can institute CAS in the territory under their jurisdiction, until places in ordinary structures can be found.

CAS are thus located within a framework that is sustained by and draws its normative force from navigating across and between multi-level legal jurisdictions and sources of law. It is a framework that builds upon a consolidated institutional apparatus (e.g. the Testo Unico), that appeals to laws promulgated in relation to specific circumstances (e.g. D.Lgs 451/1995) and combines their dicta with those contained in others (e.g. EU Directive in reception standards, Law 225/1992), to produce new dispositions and arrangements. It navigates "upwards", towards the supra-national level, by drawing principles from international obligations, by working in coordination with UN agencies such as UNHCR and the IOM, or by referring to and incorporating EU directives and regulations. It also navigates "downwards", towards the sub-national level, by specifying and altering functions and procedures of Prefetture and Questure, or by instituting administrative bodies such as Commissioni Territoriali. It sanctions procedures and specifies the content of law via Circolari, Ordinanze or Regolamenti Attuativi, administrative acts issued by the government or by Ministries, possessing normative force (see Law 400/1988, art. 17). 
This understanding of the legal location of CAS, first, confirms their centrality within EU border management. As stated by the official from the Prefettura quoted earlier, the shutting of borders is only one side of the equation and finding a (legal, in this case) location where to warehouse asylum seekers arriving in Italy is equally important. The legal location of CAS confirms and conforms with the stated governmental policy of combining actions aimed at the integration and reception of asylum seekers with policies aimed at contrasting clandestine immigration ${ }^{10}$. While the former dimension is comparatively salient in the Italian case (see Cheliotis, 2017; Papoutsi et al., 2018 for a comparison with Greece, and Squire et al., 2017, for a European-level study), it cannot be considered in isolation from the more violent forms of humanitarian border management (Pinelli, 2017, Cuttitta, 2017). CAS are an expression of the dialectic of care and control (Agier, 2012; Pallister-Wilkins, 2017) characteristic of the humanitarian management of EU borders.

Second, this understanding complicates Dikeç's (2009) dichotomy between spaces of law and of lawlessness. CAS do not appear as spaces of lawlessness created by law, in the way in which he describes, for instance, offshore processing centres. In replicating ambiguities typical of the process of incorporation of EU directives into national legislation (see Peers et al., 2015), their operations are never formally outside the law. Rather, D.Lgs 142/2015 connects and reinforces nodes of governance (see Papoutsi et al., 2018), it re-works the relative significance of national and sub-national agencies, authorities and centres of power, while confirming the territorially nested nature of these jurisdictions and sources of law. Rather than a space of law/lawlessness, the location of CAS seems to be an expression of the 'contested geographies' that the political transformations associated to the migration crisis have engendered (Painter et al., 2017).

This understanding is also a first indication of the neoliberal character of these transformations. For example, the extensive use of Circolari characterising Italy's approach to the governance of migration (Gjergji, 2013) is said to have produced a flexible, lean and efficiency-driven governance approach to migration resembling that of a private corporation and conferring salience to executive and administrative bodies in the definition of migration and asylum policies and practices (Gjerji, 2018). Similarly, the designation of irregular migration as an emergency, characteristic of the management of asylum in Italy for almost two decades, mobilises external threats to foster governance changes. Law 225/1992, which grants the government extraordinary powers whenever this is required by the intensity or extension of natural calamities, catastrophes or other events, informs Law 189/2002 defining the "ordinary" system and has recurred in all subsequent migration-related executive decisions and Decrees since then. This constitutes what some have called the institutionalisation of a "structural emergency", a practice that configures the management of asylum seekers in problematic ways as it eliminates public scrutiny over the disbursement of resources (Vrenna and Biondi dal Monte, 2011). Such practice also alters, in fact it "compresses", the relative autonomy of local administrations (ibid), as discussed in the following two sections.

\section{Allocating asylum seekers to CAS in Macerata}

\footnotetext{
"We face daily arrivals in this period. We get a phone call from the Ministry or the Prefettura of migrants' arrival telling us that X number of persons will arrive tonight. We call NGOs and the machine starts". This is how Social Services Director of the Macerata Prefettura explained to me the arrival of over 90 asylum seekers during the weekend, a ten per cent increase in the total stock. The previous week (10 to 15 July 2017), news bulletins reported
} 
the interception of 2500 asylum seekers in the Mediterranean, some of whom made their way to Macerata. Why there, though?

The previous section discussed the institutional framework used to locate within the law those asylum seekers exceeding the "ordinary" reception system's capacity. Yet this is only part of the governance problem engendered by the crisis, as those same asylum seekers, in their embodied connotation, need to be physically located somewhere. There are 65 CAS in Macerata province (see Fig.2) and over 3000 across Italy ${ }^{11}$, and this section identifies the governance mechanism that define their allocation to this province. It foregrounds different territorially-inscribed and nested administrative jurisdictions, all of which are invested by the EU border regime.

Most asylum seekers hosted in Macerata's CAS at the time of field research were disembarked in an Italian port after being intercepted in the central Mediterranean in the context of SAR operations. The latter are variously performed by military vessels involved in humanitarian border management operations, humanitarian NGOs, and "accidental humanitarians" such as crews of cargo vessels (Stierl, 2018: 704). Once disembarked, they had the strength of mind to tick the right box in the questionnaire they would have been asked to fill, enquiring, amongst other things, about the reasons for their presence in Italy. By ticking the right box, they were presumed to be in Italy to seek asylum, a crucial presumption that would have regularised their stay on Italian soil. This presumption, also and simultaneously, prevented them from seeking asylum anywhere else in Europe. The transformation of an "irregular migrant" into an "asylum seeker in Italy" is thus framed by two sets of regulations concerned with the production and modulation of European space, and their evolution over the last three decades (see Campesi, 2015), and connecting the external and internal management of EU borders.

This transformation is framed, first, by regulations concerned with the military patrolling and the reinforcement of the EU Mediterranean border. EUNAVFOR MED's Operation Sophia is a military operation that began in 2015 with the explicit objective of contrasting human smuggling and trafficking. It is part of a broader range of initiatives aimed at reinforcing EU borders, which include bilateral and regional agreements and initiatives (Pinelli, 2017). It replaced the Italian Navy's Operation Mare Nostrum (running between late 2013 and 2014), which instead had as its explicit mission the rescuing of migrants at sea (see Tazzioli, 2015; Heller et al., 2014; Garelli and Tazzioli, 2018 for more detailed accounts of this evolution). Mare Nostrum operations were terminated amidst disputes between Italy and the EU over "burden sharing" (Bevilacqua, 2017). These disputes were not only about the sharing of costs involved, or EU's pressures on Italy to transpose asylum Directives (Zaun, 2016). They most profoundly revolved around the responsibilities to process asylum seekers and to Italy's "disinclination to fingerprint and assist rescued migrants once disembarked, thereby enabling their further movement across EU space" (Heller and Pezzani, 2016, unpaginated; see also Cuttitta, 2014; Tazzioli, 2015).

Second, while SAR procedures transform Italian ports into the most likely place of disembarkment for migrants intercepted in the central Mediterranean, EU Regulation 604/2013 (aka Dublin 3) transforms Italy into the "first country of asylum", therefore responsible to adjudicate on the claim and to host asylum seekers until the process of adjudication is complete. Dublin regulations confine asylum seekers disembarked in Italy within Italian soil. They are invoked to deny access to or to push back into Italy those who attempt to make their way north, in places like Ventimiglia and Como, at EU's internal borders. They are also used to return to Italy those migrants who have "left their finger in 
Sicily", as two asylum seekers who had been caught by police in Northern Europe described the compulsory fingerprinting they were subjected to upon disembarkment.

The transformation of EU member states' sovereign privileges and duties, their external projections and the re-working of jurisdictions at sea, as much as the processes transforming southern European countries into an EU internal containment rung associated to these regulations (see also European Commission, 2015) have already been successfully dissected (Heller and Pezzani, 2014; Kasparek, 2015; Stierl, 2017; to name a few), and do not need to be revisited here. What is perhaps less dissected is how, once confined in Italy by such regulations, "asylum seekers in Italy" are dispersed into CAS throughout its territory. Here numerous other sites of institutional bargaining and contestations appear, at each of the governance levels defining the Italian state's territorially-inscribed administrative structure, made up of Regions, Provinces and municipalities. Much like in relation to the previous section's discussion, these processes (attempt to) transform their relative position, autonomy and competences.

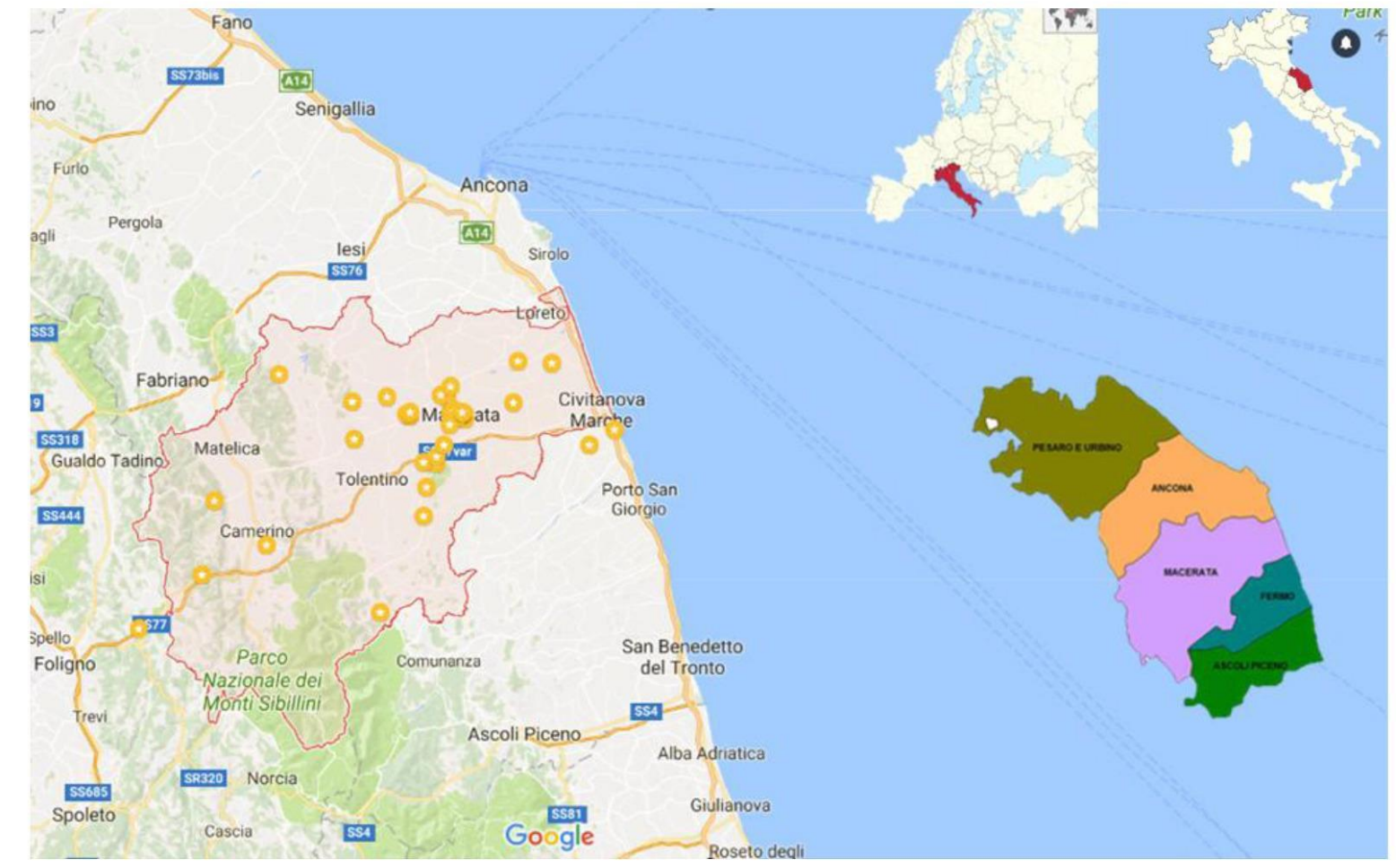

Fig. 1 Map of the Macerata province. The red-shaded area identifies the provincial jurisdiction. Stars identify the location of 65 CAS present in the province. The majority are apartments in and around Macerata city, which at this scale cannot be clearly identified. I visited 26 CAS, of which three outside the province, which are marked in the map as well. Inset, map of Europe, of Italian regions (Marche region highlighted), and of the five provinces in the Marche region.

Indeed, in parallel to the proliferation of legislative measures described in the previous section, the (claim to) crisis engendered a series of governance transformations aimed at defining the allocation of asylum seekers across the Italian territory. In July 2014, the government summoned representatives of regions and local administrations to a "Unified Conference", a legally-sanctioned national coordinating table with the function of defining Intese, i.e. binding understandings concerned with the harmonisation of national and regional laws, the definition of common positions, and the attainment of common objectives. The 
Conference devised the first National Plan to deal with the extraordinary influx of asylum seekers, an attempt to move out of the "emergency" phase of 2011/12 described in the previous section, and to establish a governance system cutting across all administrative levels.

The Plan defined procedures and coordinating mechanisms for the allocation of asylum seekers to each Italian Region taking into consideration proposals by the association of Italian municipalities (ANCI) and other such bodies, and asserting the principle of "diffuse reception", i.e. the dispersal of asylum seekers across administrative jurisdictions. Such system would be based on a fair and honest cooperation between administrative levels, which, in practice, meant using social services' transfers from the central government to each Region as allocation criteria. The Marche region, for example, would receive 265 asylum seekers per 10,000 to be allocated, as it drew $2.65 \%$ of the total government transfers. The Lombardia region, drawing the largest share of such transfers at $14.15 \%$, would host 1.415 asylum seekers per 10.000 arrivals (Ministero dell'Interno, 2016).

Further down the administrative structure, the Plan envisaged Regional Coordinating Tables, with representatives of regions, provinces and municipalities, with the objective of implementing locally the nationally agreed strategy. It also attributed competences to Prefetture in the regional capital (Prefettura of Ancona, in the Marche case) to activate coordinating mechanisms for the allocation of the regional quota of asylum seekers across each province. In the Marche region, for instance, allocation quotas across Provinces were established using a criterion that combined the share of funds drawn by each province from the regionally-disbursed EU Social Fund (a fund that promotes occupational opportunities and industrial development), and the number of residents in each province. On these bases, Ancona would be allocated $28 \%$ of the regional quota of asylum seekers, Ascoli Piceno 13\%, Fermo 11\%, Pesaro Urbino 25\%, and Macerata 23\% (interview, Prefettura Ancona ).

The Plan drawn was successful in achieving its stated aims on several counts. First, its principles were reiterated and adopted in D.Lgs142/2015 (art.16), the one establishing CAS mentioned in the previous section. Second, it centrally orchestrated a lean coordinating mechanism to govern the allocation of asylum seekers across the 20 Italian regions, which effectively reduced the pressure on regions of first arrival. For instance, in December 2013 Sicily hosted $42 \%$ of the total number of asylum seekers, but this share diminished to $13 \%$ by December 2015. During the same period, regions like Veneto and Toscana, which hosted 1\% of the total, or Lombardia $2 \%$, saw their share increasing to $9 \%, 8 \%$ and $14 \%$ respectively (Ministero dell'Interno, 2016). Indeed, by 2016 the share of transfers from the central social services fund to each region and the share of asylum seekers hosted in each region effectively mirrored each other, as hoped for in the Plan.

Third, such coordinating mechanism was also flexible and functioned as an important relay to adjust the allocation of asylum seekers, both upwards and downwards, a demonstration of the integrated nature of EU border management apparatus across governance levels. Upwards, i.e. from the provincial level to the Ministry of Interior, specific territorial contingencies were taken into consideration and used to adjust criteria. In the case of the Marche region, this most notably refers to the earthquake of 2016, because of which no asylum seekers would be allocated to three provinces for several months (interview, Prefettura Ancona). Downwards, i.e. from the Ministry of Interior to the provincial level, the coordinating mechanisms devised by the Plan would work to relay EU Decisions. This was so, for instance in relation to "relocation quotas" (Ministero dell'Interno, 2016). The latter were sanctioned by the nolonger-in-force EU Council Decisions 1523/2015 and1601/2015, which affirmed that several thousand migrants in clear need of protection would be relocated from Italy to the territory of 
the other Member States. This Decisions shaped allocation procedures in relation to the choice of port of disembarkation for ships involved in SAR operations, or preferential allocation channels opened for asylum seekers of nationalities that could qualify for relocation (ibid., pp. 14-18).

Performatively, furthermore, the Plan was also successful in asserting the authority of the Ministry of Interior in asylum matters across the Italian territory and vis-à-vis the EU and its "neighbourhood". If on one side, the Ministry was actively involved in the disruption of migration routes and the externalisation of the EU border (see above) and in negotiating the implementation of relocation quotas at EU level, on the other side, its executive decisions were ever more engrained across administrative levels. The national coordinating table expressed through the Unified Conference would draw a Plan, which would be implemented by regional coordinating tables whose authority is vested in the Ministry of Interior's provincially-decentralised Prefetture, with all decisions and procedures sanctioned by Ministerial decree, within the parameters set by EU directives (see also Circolare Ministero dell'Interno 11 October 2016).

The Plan, however, was far less successful in getting municipalities involved. The principle of "diffuse reception", the definition of regional allocation quotas, and the decentralisation of decisions regarding provincial allocations to Prefetture in the regional capital, in fact, does not force municipalities to actively engage in the reception of asylum seekers. The SPRAR network is led and managed by municipalities, and functions on an exclusively voluntary basis. Municipalities can be encouraged and Prefetture engage with them in a daily and capillary process of concertazione (bargaining), dialogue and participation (SPRAR, 2017: 33), a testimony of their increased territorial engagement and pivotal role. Municipalities are also incentivised through monetary compensations, as per Law 193/2016, which envisages fiscal contributions for local administrations opening SPRAR, including a $€ 500$ bonus per year per migrant, without restrictions on spending (i.e. with funds not tied to migrant-related expenditures). Finally, the 2016 National Allocation Plan (see Circolare Ministero dell'Interno 11 October 2016) offers municipalities a so-called "safeguard clause", which exempts them from having to host CAS instituted by the Prefetture, if they voluntarily host asylum seekers through SPRAR. Seen in the opposite direction, the clause also implies that municipalities that, for whatever reason, are unwilling or unable to open SPRAR may have CAS instituted by the Prefettura in their territory. Indeed, as per D.Lgs 142/2015 Prefetture can institute CAS through public tenders with municipalities only notified.

This implies that the Ministry of Interior's provincially-decentralised territorial manifestation, i.e. the Prefettura, acquires a central role in the management of asylum-related matters, to the detriment of parliament's and municipalities' oversight. The co-ordinating mechanisms devised by the Plan mirror the transformations discussed in the previous section with regards to the legal location of CAS, as they seem to operationalize a condition of "structural emergency" whereby the executive can define dispositions and procedures regarding CAS without them being examined by parliamentarians. For sure, the Parliament exercises overall control on the reception system through a Parliamentary Commission ${ }^{12}$, yet this control seems diluted in relation to CAS. The monitoring functions performed by the Commission happen ex-post, through visits and the acquisition of relevant information from regional and provincial state bodies, but they are set against a highly dynamic and fluid context. Furthermore, monitoring is mostly concerned with the material living conditions inside CAS and with expenditures. In relation to their location, the main concern of this article, finally, albeit the Commission emphasises the need to move beyond an emergency approach to reception, it does not question the need for CAS. In fact, one of its Rapports ${ }^{13}$ simply restates norms contained in D.Lgs 142/2015 regarding the powers of the Prefettura to institute them. 
Similarly, this makes the Prefetture much more assertive in its relations with administrative branches of the state, such as municipalities and their (elected) mayors and councils. As a member of Ancona Prefect's Cabinet told me: "The role of Prefettura is indeed increasing. The malicious say that it was only thanks to migrants that we still have a job, otherwise we would have disappeared. Truth is that I was quite busy even before, but for sure now I am constantly involved in activities, discussions and decisions. I tour municipalities every day and engage with them constantly". While this statement should be set against the attempts to abolish the role and competences of provinces as an administrative level of the Italian state ${ }^{14}$, the statement suggests the extent to which provinces have become a crucial governance level in the functioning of the EU border regime, the lowest administrative rung of an ever-more integrated border management system.

Put differently and drawing a parallel from the discussion in the previous section, while the Plan configures the "ordinary" allocation mechanism for dispersing asylum seekers across Italian regions and provinces and relies on a voluntary adherence on the part of municipalities to become fully effective, CAS function as the extraordinary valve that provides the conditions of possibility for asylum seekers to be dispersed across Italian provinces when the ordinary mechanism is unable to. This is clearly not a smooth process, as discussed next.

\section{Locating CAS}

"It is not possible for a representative of the state, because this is what a Mayor is, to make such statements". This was the reaction of the Director Social Services of Macerata Prefettura to reports that the mayor of the municipality of Ussita was opposed to the arrival of 25 asylum seekers, in August 2016. A few days earlier I had visited the town and the hotel where these persons were supposed to be hosted. There, I interviewed the director of the organisation that was supposed to host them, a self-styled "humanitarian entrepreneur" who also managed a CAS in a northern Italian town. Earlier that year, he had won the Bando (public tender) for the "reception and assistance of non-EU foreigners seeking asylum in centres within the Macerata province to be identified by the organisations participating in the tender" organised by the Prefettura di Macerata ${ }^{15}$, which regulates the activities of contractors in charge of managing asylum seekers in the province. The arrival of the 25 asylum seekers, however, was delayed by a suspected arson attack that damaged the mattresses and rooms of the hotel he had rented to conduct his humanitarian business. When I visited the hotel, the renovation was complete, but their arrival was further delayed, at least according to the entrepreneur, by a road blockage planned by residents to prevent them from reaching the (quite remote) town. He was engaged in discussion with the mayor, and so was the Prefettura, with one of its representatives expected over the following days. The standoff involving the territorial manifestation of the Italian government, a locally-elected mayor, segments of the population of Ussita and neighbouring towns, and a businessman involved in asylum provisions was, ultimately and tragically, resolved by the earthquake that destroyed the town, in October of that year.

Still, such standoff is not an isolated incident, and I recorded similar instances in my field notes. The arrival of 12 asylum seekers in Villa Potenza, for example, was strongly ostracised by the local administration, and, post-arrival, such opposition was rendered concrete by some residents through everyday forms of racisms. In anticipation of the arrival of about 40 asylum seekers in a church-owned building in a remote fraction of the municipality of Treia, residents summoned the bishop to plead with him for this to stop. The mayor of Sarnano successfully managed to reduce by six (from 37 to 31 ) the number of asylum seekers hosted 
in a hotel in his town, because 31 was the number sanctioned in the Bando (even if the Bando allows a variation from the original number).

This section is concerned with understanding what shapes the exact location of CAS across municipalities in the Macerata province. By socially situating decisions about the opening of a CAS in one or the other municipality, it unearths the contestations, negotiations and cooptions associated to them, and highlights the centrality of contractors in shaping such geographies.

Fig. 3 lists, respectively by column, all the municipalities in the province, their resident population, the target number of asylum seekers per municipality (based on a per thousand population ratio) proposed by the Association of Italian Municipalities (ANCI) and adopted by the latest National Allocation Plan, and the presence of migrants in extra-ordinary and ordinary reception centres (CAS and SPRAR) as of 15 June 2017. In the last column, it evidences the difference between target and actual numbers. A negative number means that the municipality hosts more asylum seekers than those expected according to the allocation criteria, while a positive number demonstrates the opposite.

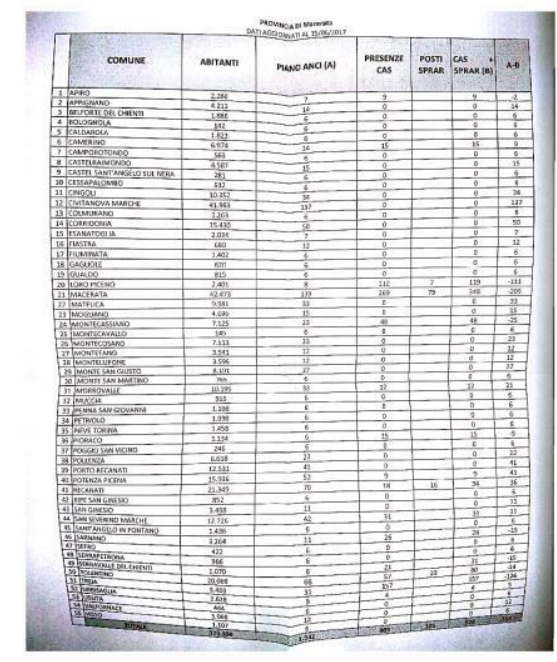

The table, first, confirms the significance of CAS compared to the ordinary SPRAR centres, also at this administrative level of data collection. Much like in the rest of Italy, CAS are central to the system. As of 15 July 2017, 77.4\% of the over 205thousand asylum seekers in Italy were hosted in CAS, with only $15.3 \%$ of them in SPRAR, and the remaining in first tier centres (SPRAR, 2017). In Macerata province this percentage is even higher, with $86.5 \%$ of asylum seekers hosted in CAS. Second, the table illustrates how very few municipalities adhere to the National Allocation Plan, and a large proportion does not have any asylum seekers' presence. This also seems to be the case across Italy, where only $40.5 \%$ of municipalities hosts asylum seekers or refugees in their administrative territory (SPRAR, 2017). Third, the table, perhaps paradoxically, also displays a few "outperformers", i.e. municipalities hosting well above the quota that is expected of them. More broadly, the unevenness of CAS across the province's municipalities indicates that the Prefettura's decision to institute them does not strictly follow an allocation model premised on the Plan discussed above. Why are CAS where they are?

First, decisions about the location of CAS across municipalities are guided by policy debates. According to interviews, the Prefettura pursues the principle of diffuse reception and aims at dispersing asylum seekers across the provincial territory, guided by the allocation Plan defined in the previous section. At the same time, it would prefer asylum seekers to be hosted in towns, as opposed to across the mostly rural territory, so they can better learn Italian and 
can more easily find work. It would also prefer centres hosting 30 to 40 asylum seekers, as opposed to small ones, so that services could be delivered to them more efficiently, without organisations running across the province to deliver such services. This seems difficult to achieve in most towns, given their size, and thus perhaps contradictory to the first point. Furthermore, each of Prefettura contractors, i.e. the NGOs, church-based cooperatives and for-profit organisations that have won the public tender, seem to be guided by other concerns and to pursue different policies. Some of them think that having asylum seekers in small towns may provoke negative reactions from residents. For them, it is better to have them dispersed across the provincial territory. For others, on the contrary, asylum seekers represent an opportunity to repopulate small towns whose resident population have been steadily declining. Others say it is not their problem to sort out the Prefettura's contradictions, especially since they are pushed to accept more and more asylum seekers. The latter prefer small centres near their main office to establish a daily contact and dialogue with beneficiaries.

Second, decisions regarding the presence/absence of CAS at the level of each municipality are more fine-grained. In some cases, such as Tolentino, their absence should be explained by reference to the earthquake and the fact that existing structures had to be evacuated. In other cases, as exemplified at the beginning of this section, their absence seems to be a direct consequence of the oppositional stance taken by elected local administrations and their constituencies. The case of "outperformers" could instead be explained by considering the location of CAS within each municipality's administrative territory. In three such municipalities (Montecassiano, Treia and Loro Piceno), CAS are far removed from the main town, albeit still within the municipality's jurisdiction. One hotel in Montecassiano, for example, hosts over 70 asylum seekers, yet nowhere near the actual town. This is even more the case in Treia, where the five CAS hosting between 20 and 40 asylum seekers each are dispersed across the administrative territory's periphery, far away from the town's centre. In Loro Piceno, the hotel hosting over 100 asylum seekers and the largest CAS in the province, is located near the main provincial road, removed from the picturesque town, which is instead perched up the hill. In the case of Civitanova Marche, the second largest town in the Province, the absence of asylum seekers could be explained by a combination of factors. Rents tend to be higher, especially so after the earthquake which saw many residents of affected areas move closer to the sea. The director of one of the largest NGOs told me instead that for them, this was a strategic choice. The pre-existing presence of criminal groups whose nationality is the same as that of most of the asylum seekers they host meant that, for them, "establishing a CAS there would have asylum seekers walk straight into the mafia, and they would immediately be perceived as pushers". Church-based groups, very active in the asylum system across Italy, would instead explain this in relation to the differently-configured territoriality of the archdioceses. While Civitanova Marche is indeed in the Macerata province, it falls under the jurisdiction of the Archdioceses of Fermo, the province south of Macerata, and most of their activities are concentrated there, where they host about 120 asylum seekers. For other persons interviewed, this is an "efficiency" question. Civitanova is too far from Macerata to make it efficient for organisations based in the provincial capital.

While insightful in relation to presence/absence of CAS in each municipality, none of these situated rationales holds the ground at provincial level. The conditions of possibility that allow some municipalities and not others to mount a seemingly successful resistance against the Prefettura's process of concertazione are not clear. Many CAS are isolated and/or small, certainly not within "efficient reach" from Macerata. The church owes buildings in almost every town and yet not all of them host asylum seekers. The landscape of the province, which sees towns usually located on hilltops and surrounded by large cultivated fields punctuated by 
farmhouses, would allow for the territorial gamesmanship described above being more frequent. Many CAS are in or nearby the centre of towns. Most CAS are apartments in Macerata town (47 out of 65 CAS), albeit these apartments only host $30 \%$ of the total of asylum seekers in the province ${ }^{16}$.

Third, a more systemic explanation emerging strongly from accounts recorded points to the availability of rural houses, hotels and apartments for the purposes of hosting asylum seekers. As per the Bando regulating the activities of contractors, in fact, it is the responsibility of participating organisations to identify a suitable building. Contractors are those who seek places where to host asylum seekers, those who rent accommodation from willing landlords, and those who, on those bases, participate in the public tender. This opens a whole new set of explanations, different from those delineated so far, which decisively contributes to explain the location of CAS across municipalities.

As recorded in my field notes, church-based groups usually have their own buildings, while NGOs and for-profit contractors must rent them. For larger organisations this may not be a problem, as they are able to offer secure and long-term contracts and bank guarantees, but smaller ones face more hurdles. Local contractors are at an advantage vis-à-vis those coming from other regions of Italy, let alone from abroad, as they have better knowledge of the territory and can more easily mobilise their networks. Some of the for-profit organisations (humanitarian entrepreneurs) may be looking for the cheapest accommodation, regardless of the policy criteria detailed above. In some towns, the opposition to the arrival of asylum seekers translates in houses not being made available for the purposes of hosting asylum seekers, despite the 'for rent' signs visible in their streets. Many landlords, on the contrary, call NGOs to offer them buildings, most often located in remote corners of the Province. The same do some Hotel owners, whose business in many cases seems to survive only thanks to their renting rooms for the purposes of hosting asylum seekers. As put by the Director Social Services of the Macerata Prefettura: "The location of centres is premised on the availability of each organisation. Every day we receive from them the number of available places and we communicate it to the Ministry, which has an updated picture of available places across Italy".

Indeed, while the previous section identified the top-down centrally-orchestrated institutional mechanisms that shape the location of CAS from the EU level down to provincial administrative jurisdictions, this section has offered instead a bottom up explanation of their location. The latter is centred on fluid and situated social processes of contestation, cooptation and bargaining, which continue to see the Prefettura in a pivotal role, but at the same time de-centre decisions about and privatise the dynamics that explain the 'where' of asylum. On one side, these processes confirm the nested and peripheral nature of provincial-level asylum dynamics, as they strictly unfold within the parameters set by the institutional mechanisms defined in the previous sections. On the other side, by providing a physical location where to warehouse asylum seekers, they resolve the tensions associated to the humanitarian dimensions of EU border management, thus sustaining the latter's exclusionary violence. The dialectic of care and control expressed by the humanitarian management of EU borders, which transforms irregular migrants intercepted in the Mediterranean into "asylum seekers in Italy", makes the provincial level a crucial one, as this is where the tension associated to such dialectic are finally resolved. This is what makes provincial-level asylum dynamics central to such management's functioning.

\section{The neoliberal location of asylum}


Returning to Macerata in July 2018 much seems to have changed. This was to be expected considering the events of 3 February 2018, when an Italian man shot six black persons, apparently enraged by the murder of an Italian woman a few weeks earlier (committed, allegedly, by two Nigerian men). These events uncovered a latent discontent amongst the population and produced a backlash against migrants, especially those of African origin, with racist abuses becoming (even more) widespread, and put the spotlight on the Prefettura contractors, accused of enriching themselves by hosting an ever-increasing number of asylum seekers. It also produced changes in the reception system. After the shooting, the Prefect of Macerata wrote a formal note to the Ministry of Interior requesting to stop the allocation of asylum seekers to the Province, and no new arrivals have been recorded since then. On 5 March 2018, the municipality of Macerata invoked the safeguard clause and, consequently, all CAS in Macerata town were closed, bar a very limited number hosting unaccompanied minors and families. "This is not what the safeguard clause is meant to do", an official in the Prefettura told me. The municipality had in fact expanded the number of SPRAR facilities just a few months earlier taking into consideration the presence of asylum seekers in CAS. "If anything, they should have invoked it then". Those that were hosted in a CAS in Macerata were relocated to other such facilities throughout the province. Many asylum seekers have left the province without waiting for their claim to be adjudicated upon by the Commissione and attempting to make their way to other parts of Europe. The 468 asylum seekers that remain in the 37 still functioning CAS, spend their days inside them, daring a trip to Macerata town only every so often to buy food or to recharge their phone, and then swiftly returning 'home'.

These dynamics somewhat anticipated broader transformations in the EU border regime. Compared to the previous year, the overall number of irregular arrivals has decreased by $25 \%$, at European level in the first quarter of $2018^{17}$, and by $80 \%$ in Italy in the first six months of $2018^{18}$. The newly installed (April 2018) Italian government closed its ports to humanitarian NGOs and attempted to deny access to vessels involved in Operation Sophia, unleashing disputes amongst various ministries (Interior, Foreign Affairs, Infrastructure) over who can or cannot deny access to Italian ports, and amongst EU member states over SAR procedures. The Minister of Interior issued a directive in June 2018 inviting Commissioni Territoriali to operate with more rigour and scrupulousness in the adjudication of asylum claims and to take into consideration the interests of Italians at the same time as those of asylum seekers. The Prefect acting as President of the National Commissione Territoriale, which exercises orientation and coordination functions, followed on from this directive, inviting the presidents of the various Commissioni Territoriali through a formal note issued on 13 July 2018 to reduce the number of humanitarian protection status awarded to asylum seekers. This contravenes the legally-sanctioned principle of individual examination of asylum claims and was fiercely opposed by many ${ }^{19}$. Another directive issued by the Minister of Interior on 23 July 2018 indicates that further changes in the reception system are to be expected. These changes will be aimed at a rationalisation of reception facilities motivated by cost reductions and efficiency. Meanwhile, as of 12 July, the number of recorded deaths in the Mediterranean in 2018 has reached 1422.

These two sets of dynamics overlap. Both evidence the perpetuation of violent and exclusionary forms of border management and a decreasing relevance of humanitarianism in the management of EU borders (Campesi, 2018), a recalibration of the kinds of activity that are feasible and appropriate for nonmarket institutions to engage in (Bruf, 2017), and a set of contestations (Painter et al., 2017). This overlap is not coincidental. Indeed, the above analysis proceeded on the conviction that the relatively peripheral nature of places like Macerata does not make them less significant to capture broader transformations within the 
EU border regime. On the contrary, these marginal places offer great analytical insights on the monumental political transformations that are investing Europe as a result of the migration crisis (Painter et al., 2017); or, at least, of the claim to crisis (Roitman, 2013).

Based on this conviction, the three substantive sections of the paper mapped the location of CAS within EU border management, hoping to gain insights on the character of these transformations. The mapping exercise built upon and complicated Dikeç's (2009) understanding of the "where" of asylum. Section 2 was concerned with the legal location of CAS, and identified the European Directives, Italian laws, Ministerial Decrees and executive orders that define the location of CAS within Italian law. It illustrated the multi-level jurisdictions and sources of law that sustain the Decree instituting CAS and in so doing, it suggested that while confirming the territorially nested nature of these jurisdictions, the Decree also creates new governance nodes and assemblages (see Papoutsi et al., 2018). The following two sections mapped the geographical location of CAS within the Macerata province, and explained it as the result of a double pressure. From the top down, Section 3 identified the institutional mechanisms that respond to the need to allocate, across Europe and Italy, those irregular migrants that reach European soil. From the bottom up, Section 4 provided a series of socially situated and contextual explanations, which ultimately seem to revolve around the availability of structures that can be used for the purposes of hosting asylum seekers.

All three sections confirm the centrality of CAS in Macerata within the humanitarian management of EU borders. Both legally and geographically, CAS offer an "extraordinary" location where to warehouse asylum seekers in excess of the "ordinary" system's capacity. As an institutional location developed to obviate the inadequacy of previous laws concerned with the reception of asylum seekers and as a geographical location where to host asylum seekers in their embodied connotations, CAS are an integral component of the dialectic of care and control that characterises the humanitarian management of EU borders; in fact, a crucial one that allows to maintain the humanitarian pretences of the EU border regime, resolving one of its latent tensions.

All three sections, furthermore, confirm the need to increase analytical awareness towards the territoriality of the EU border regime. Over the last few years much attention has, correctly, been devoted to processes of externalisation and to the mobility of EU borders, yet far less scrutiny has been devoted to the ways in which the EU border regime configures itself territorially. The previous analysis has demonstrated the significance of territorially-nested jurisdictions for the functioning of such regime. This is so, perhaps evidently, in relation to the legal location of CAS, whose normative content is framed by, appeals to and reworks international, bilateral and national sources of law, thus confirming the significance of the territorial jurisdictions where these are developed and applied. This is also so in relation to the geographical location of CAS. The complex and contested allocation mechanisms that define the exact location of CAS across municipalities underscore the significance of national as much as regional, provincial and municipal administrative jurisdictions. Mapping the spatiality of EU borders requires an awareness both to processes that externalise borders and render them mobile, and to processes that reinforce territorially-inscribed jurisdictions (Novak, 2017).

Such conceptualisation of the spatialities of EU borders, finally, sheds light on the forces able to flexibly articulate themselves across both mobile and territorial dimensions (Novak, 2011), and all three sections have been concerned with understanding the character of the transformations engendered by the crisis. While it could be possible to interpret the evolution of the reception system described above as a frantic response to the urgent need to adapt and 
transform the existing framework to the crisis, it appears from the above discussion that these transformations are geared towards the structural reconfiguration of governance mechanisms, a reconfiguration that is neoliberal in its character. This is so in terms of the governmentorchestrated and yet decentralised privatisation of the management of CAS (see Darling, 2016); of the increased frequency with which laws and normative documents that weaken the critical scrutiny of democratically-elected officials are enacted in the name of the "crisis" (see Bruf, 2017); of the increased reach of the EU border regime across administrative jurisdictions, reaching as far as "peripheral" municipalities (see Allen and Cochrane, 2010).

Indeed, if on one side, as correctly pointed out by de Genova (2017) and others, the externalisation and virtualisation of EU borders need to be understood as part of the ongoing reconfiguration of a planetary regime dedicated to the neoliberal government of human mobility, on the other side, the force of neoliberalism is not exhausted by this imperative. Much like in relation to the imposition of Structural Adjustment Programmes in developing countries (Johnston and Saad-Filho, 2005) or indeed Europe (Bruf, 2017), EU border management is an engine of state transformation. It shifts the relative significance of ministries and power centres within the state apparatus and across administrative levels, notably, in this case, in favour of the Ministry of Interior. It streamlines and de-centres governance mechanisms favouring the rule of the executive over that of elected parliamentarians and local administrators and fosters such mode of governance through legal and administrative changes. It privatises decision-making processes, transferring public authority to private organisations. In sum, it weakens processes of democratic accountability. Neoliberalism is an all-pervasive force able to operate across both mobile and territoriallyinscribed spatialities.

Clearly, this is not a smooth process, and peripheral locations such as the Macerata province are excellent sites to capture the contested geographies associated to these transformations (Painter et al., 2017). Whether the latter will lead to the realisation of an EU superstate (ibid) or to forms of authoritarian neoliberalism (Bruf, 2017) that reassert national sovereignty as the locus of territorial governance and control, remains to be seen. For sure, what can be learned about the European migration crisis by studying it at its margins is that these transformations do not exclusively invest migrants. The efficiency-driven governance models, the weakening of democratic accountability, and the privatisation of public functions that these transformations foster, necessarily invest migrants and non-migrants alike.

This recognition is important in the current political debate about the crisis, on two counts. First, because foregrounding the all-pervasive force of neoliberalism may well foster the identification of terrains of struggle that, much like neoliberalism itself, cut across "dangerous divides" (Anderson, 2013) between migrants, whether excluded or subordinately included by borders, and non-migrants. Second, because these terrains are likely to be different in different contexts, considering the variegated configurations of neoliberalism across scales (Peck and Tickell, 2002). As the previous section suggests, the crevices used by EU border management to resolve its latent tensions are situated and fluid, and so must be our responses.

\footnotetext{
${ }^{1}$ As of $15^{\text {th }}$ September 2017. Data collected during field research, see later in the text for timeframe of data collection and updates.

${ }^{2}$ The number refers to non-EU28 asylum seekers who have lodged an asylum application in a EU28 country for the first time. I am using the EUROSTAT dataset, available at

http://appsso.eurostat.ec.europa.eu/nui/submitViewTableAction.do I am taking the year 2011 as a referent, as this coincides with the s.c. Arab spring and the beginnings of turmoils in the Middle East that have engendered large number of asylum application in Europe. In the case of arrivals to Italy, the referent of this article, 2011
} 
also marks with the year in which asylum applications more than doubled compared to previous years, and in which institutional responses by the Italian government began a rapid transformation, as detailed later in the text.

${ }^{3}$ Press release by ISMU available at http://www.ismu.org/wp-content/uploads/2017/02/Comunicato-Ismurichiedenti-asilo febbraio-2017.pdf, see also note 6 below.

${ }^{4}$ See Directive 2011/95/EU of the European Parliament and of the Council of 13 December 2011, available at https://eur-lex.europa.eu/legal-content/en/TXT/?uri=CELEX:32011L0095 (accessed 6 July 2018).

${ }^{5}$ These time limits are confirmed by art. 27 comma 2 of the D.Lgs 25/2008. See Nascimbene, 2003 for a discussion on the ambiguities concerning time limits.

${ }^{6}$ Data are extremely difficult to obtain, as I realised during field research, when access to it was constantly hampered by competent authorities. Here, I am using data from Papavero, 2015, from a factsheet contained in a press release by ISMU available at http://www.ismu.org/wp-content/uploads/2017/02/Comunicato-Ismurichiedenti-asilo_febbraio-2017_.pdf and from the statistical fact sheet of the Ministero Interno available online online at http://www.libertaciviliimmigrazione.dlci.interno.gov.it/it/documentazione/statistica/i-numeri-dellasilo (accessed 16 November 2017). The first shows a graph from 1997 to 2014, but without a table indicating precise number of arrivals by year. The second one displays the number of arrivals and number of asylum requests by year, and thus their gap. The third, in its 1990-2016 "statistical summary", only displays the number of formal asylum requests. As an indicator of the significance of the gap between arrivals and asylum requests, the ISMU factsheet records the number of arrivals in 2011 as 62.692 persons and that of asylum requests as 37.350.

Newspapers regularly report arrival numbers, and while I have taken them into consideration when providing estimates in this paper, I have not used their figures as they often leave their data unreferenced.

${ }^{7}$ See http://www.osservatoriomigranti.org/?accoglienza-normativa-nazionale and www.sprar.it/wpcontent/uploads/2016/06/Documenti/.../Raccolta-normativa.pdf for an excursus (accessed 16 November 2017)

${ }^{8} \mathrm{See}$ http://old.asgi.it/home asgi.php\%3Fn=1550\&l=it.html for relevant documents. (accessed 16 November 2017)

${ }^{9}$ See Lunaria, 2013, p.92, note 74.

${ }^{10}$ See for example http://www.interno.gov.it/it/temi/immigrazione-e-asilo/politiche-migratorie. Most of the Decrees and Law cited in this section cover both aspects.

11 The number of CAS in Macerata is as of September 2017.

${ }^{12}$ See documents related to the Commissione Parlamentare on asylum and reception issues at http://www.camera.it/leg 17/1281?shadow_organo_parlamentare=2649\&shadow_organo=102\&natura $=\mathrm{M}$

${ }^{13}$ See http://www.camera.it/_dati/leg17/lavori/documentiparlamentari/IndiceETesti/022bis/006/INTERO.pdf pages 65-66.

${ }^{14}$ The s.c. Delrio law of 2014 emptied many of the competences of Provinces, redistributing them to municipalities and newly constituted Metropolitan cities. Provinces are enshrined as an administrative level of the Italian state in the constitution. Their abolishment was proposed as part of a constitutional reform aimed at transforming the Italian parliament in a 2016 referendum, which was rejected by the electorate.

${ }^{15}$ The tender documents are available at http://www.prefettura.it/macerata/news/Bandi_di_gara_e_concorsi47328.htm (accessed 28 November 2017)

${ }^{16}$ Data as of 29 August 2017, from Prefettura Macerata

${ }^{17}$ http://ec.europa.eu/eurostat/statistics-

explained/index.php/Asylum_quarterly_report\#Main_trends_in the numbers_of_asylum_applicants

18 http://www.interno.gov.it/it/sala-stampa/dati-e-statistiche/sbarchi-e-accoglienza-dei-migranti-tutti-i-dati

${ }^{19}$ See ASGI note at https://www.asgi.it/asilo-e-protezione-internazionale/esame-equo-e-indipendente-delledomande-di-asilo-gravissimo-tentativo-di-stravolgimento-della-norma-da-parte-della-commissione-nazionale/

\section{References}

Agier, M. (2011) Managing the Undesirables: Refugee Camps and Humanitarian Government Trans

David Fernbach. Cambridge: Polity Press. 
Allen, J., Cochrane, A. (2010) Assemblages of state power: topological shifts in the organization of government and politics. Antipode 42(5), 1071-1089.

Anderson, B. (2013). Us and them? The dangerous politics of immigration control Oxford: Oxford University Press.

Andersson, R. (2014). Illegality, Inc: Clandestine migration and the business of bordering Europe, Oakland: University of California Press.

Bevilacqua, G. (2017). Exploring the Ambiguity of Operation Sophia Between Military and Search and Rescue Activities in Andreone G. (ed) The Future of the Law of the Sea: Bridging Gaps Between National, Individual and Common Interests Cham: Springer International Publishing, 165-189

Bruff, I. (2017). Cease to exist? The European 'social' model and the hardening of 'soft' EU law. In C.

B. Tansel (Ed.), States of Discipline: Authoritarian Neoliberalism and the Contested Reproduction of Capitalist Order (pp. 149-169). London, UK: Rowman \& Littlefield International.

Campesi, G. (2015). Polizia della frontiera : Frontex e la produzione dello spazio europeo Roma : DeriveApprodi

Campesi, G. (2018). Seeking Asylum in Times of Crisis: Reception, Confinement, and Detention at Europe's Southern Border. Refugee Survey Quarterly, 37(1), 44-70.

Casas-Cortés M., Cobarrubias S., Pickles J. (2015). Riding routes and itinerant borders: Autonomy of migration and border externalization Antipode, 47(4), 894-914.

Cheliotis, L. (2017). Punitive inclusion: The political economy of irregular migration in the margins of Europe. European Journal of Criminology, 14(1), 79-99.

Cuttitta, P. (2014). From the Cap Anamur to Mare Nostrum: Humanitarianism and Migration Controls at the EU's Maritime Borders. In Claudio Matera and Amanda Taylor (eds) The 
Common European Asylum System and Human Rights: Enhancing Protection in Times of Emergencies Centre for the Law of EU External Relations, Den Haag: Asser Institute.

Cuttitta, P. (2017). Delocalization, humanitarianism, and human rights: The Mediterranean border between exclusion and inclusion Antipode 50(3), 783-803.

Darling, J. (2016). Privatising Asylum: Neoliberalisation, Depoliticisation and the Governance of Forced Migration. Transactions of the Institute of British Geographers, 41(3), 230-243.

Davies, T., Isakjee, A., and Dhesi, S. (2017). Violent Inaction: The Necropolitical Experience of Refugees in Europe. Antipode, 49, 1263-1284.

De Genova, N. (ed) (2017). The Borders of 'Europe': Autonomy of Migration, Tactics of Bordering Chapel Hill: Duke University Press.

Dikec, M. (2009). The 'where' of asylum Environment and Planning D: Society and Space 27, 183-9.

Dines, N., Montagna, N., \& Vacchelli, E. (2018). Beyond Crisis Talk: Interrogating Migration and Crises in Europe Sociology 52(3), 439-47.

European Commission (2015). Communication from the Commission to the European Parliament, the Council, the European Economic and Social Committee and the Committee of the Regions. A European Agenda on Migration. COM (2015) 240. Brussels.

Fassin, D. (2012). Humanitarian reason: A moral history of the present times. Berkeley: University of California Press.

Tazzioli, M., \& Garelli, G. (2018). Containment beyond detention: The hotspot system and disrupted migration movements across Europe. Environment and Planning D: Society and Space. https://doi.org/10.1177/0263775818759335

Garelli, G., Sciurba, A., and Tazzioli, M. (2017). Mediterranean Movements and Constituent Political Spaces: An Interview With Sandro Mezzadra and Toni Negri. Antipode, early access Published 6 October 2017. doi: 10.1111/anti.12346. 
Gjergji, I. (2013). Circolari amministrative e immigrazione Milano: Franco Angeli.

Gjergji, I. (2018). La governance delle migrazioni, ovvero il metodo toyota nella gestione pubblica di un fenomeno. Quaderno n. 5-Master in immigrazione, genere, modelli familiari e strategie di integrazione, 201, 27-54.

Heller, C. and Pezzani, L. (2016). Ebbing and Flowing: The EU's Shifting Practices of (Non-)Assistance and Bordering in a Time of Crisis Near Futures Online 1 "Europe at a Crossroads" (March 2016).

Heller, C., and Pezzani, L. (2014). Liquid Traces: Investigating the Deaths of Migrants at the Maritime Frontier of the EU In Forensic Architecture (ed) Forensis: The Architecture of Public Truth. Berlin: Sternberg Press, 657-685

Hess S. and Kasparek B. (2017). Under Control? Or Border (as) Conflict: Reflections on the European Border Regime Social Inclusion 5(3), 58-68

Johnston, D., Saad Filho, A. (eds.) (2005) Neoliberalism: A Critical Reader London: Pluto Press.

Kasparek, B. (2015). Complementing Schengen: The Dublin System and the European Border and Migration Regime in Harald Bauder and Christian Matheis (eds) Migration and Borders Here and Now: From Theorizing Causes to Proposing Interventions. London and New YorkY: Palgrave MacMillan.

Lendaro, A. (2016). A 'European Migrant Crisis'? Some Thoughts on Mediterranean Borders. Studies in Ethnicity and Nationalism 16, 148-157.

Lindley A. (ed.) (2014). Crisis and Migration: Critical Perspectives London: Routledge Lunaria (2013). I Diritti non sono un "costo", available at http://www.lunaria.org/wpcontent/uploads/2013/11/i diritti non sono un costo-tot.pdf accessed 28 July 2018. 
Mainwaring, C., Silverman, S.J. (2017). Detention-as-Spectacle International Political Sociology 11(1), 21-38.

Marois, T., Pradella L. (eds.) (2014). Polarizing Development: Alternatives to Neoliberalism and the Crisis London: Pluto.

Mezzadra S. (2015). The proliferation of borders and the right to escape. in Y. Jansen, R. Celikates and J. de Bloois (eds), The Irregularization of Migration in Contemporary Europe. Detention, Deportation, Drowning London - New York: Rowman \& Littlefield, 121-135.

Ministero dell'Interno (2016). Piano di Accoglienza 2016. Tavolo di Coordinamento regionale Rome, available online at www.vita.it/attachment/d601c9b0-b314-46ba-b708-d4341546c2d9/ (accessed 16 November 2017)

Moreno-Lax, V. (2017). Accessing asylum in Europe: extraterritorial border controls and refugee rights under EU law. Oxford: Oxford Studies in European Law

Nascimbene, B. (2003). Nuove norme in materia di immigrazione. La legge Bossi - Fini: perplessità e critiche. Corriere Giuridico 4, 532-540.

Novak, P. (2017) Back to Borders Critical Sociology (43)6, 847-864.

Novak, P. (2011) The Flexible Territoriality of Borders Geopolitics (16)4, 741-767.

Pallister-Wilkins, P. (2015). The humanitarian politics of European border policing: Frontex and border police in Evros International Political Sociology 9(1), 53-69.

Painter, J., Papada, E., Papoutsi, A., and Vradis, A. (2017). Hotspot politics-or, when the EU state gets real Guest editorial. Political Geography 60, 259-260.

Papoutsi, A., Painter, J., Papada, E., and Vradis, A. (2018). The EC hotspot approach in Greece: creating liminal EU territory, Journal of Ethnic and Migration Studies, pre-published online 30 May 2018, DOI: 10.1080/1369183X.2018.1468351

Peck, J. and Tickell, A. (2002). Neoliberalising space Antipode, 34(3), 380-404. 
Peers, S., Moreno-Lax, V., Garlick, M. and Guild E. (2015) EU Immigration and Asylum Law (Text and Commentary) Second Revised Edition Volume 3: EU Asylum Law. Leiden: Martinus Nijhoff Publishers.

Pinelli, B. (2017). Control and abandonment: The power of surveillance on refugees in Italy, during and after the Mare Nostrum operation. Antipode 50(3):725-747.

Roitman, J. (2013) Anti-Crisis Chapel Hill: Duke University Press.

Rumford, C. (2008). Cosmopolitan Spaces: Europe, Globalization, Theory London: Routledge.

Rondinelli, D. and Cheema, G.S. (2003) The Competent State: Governance and Administration in an Era of Globalization, in D. A. Rondinelli and G. S. Cheema (eds.) Reinventing Government for the Twenty-First Century. State Capacity in a Globalizing Society, 243-260. (Kumarian Press).

Saad-Filho, A., Fine, B. (2017). Thirteen Things You Need to Know About Neoliberalism Critical Sociology 43(4-5), 685-706.

SPRAR (undated). Materiale Didattico. Decreto Legislativo n. 140 - 2005. Available online www.sprar.it/wp-content/.../Decreto legislativo n 140-2005.pdf accessed 6July2018

SPRAR (2017). Rapporto sulla protezione internazionale in Italia. Available online www.sprar.it/wp.../2017/11/2-Sintesi-Rapporto-Protezione-2017.pdf Accessed 8 December 2017.

Squire, V., A. Dimitriadi, N. Perkowski, M. Pisani, D. Stevens, and N. Vaughan-Williams. 2017. “Crossing the Mediterranean Sea by Boat: Mapping and Documenting Migratory Journeys and Experiences." Final project report. www.warwick.ac.uk/crossingthemed.

Stierl, M. (2017). Excessive Migration, Excessive Governance: Border Entanglements in Greek EUrope in Nicholas De Genova (ed) The Borders of 'Europe': Autonomy of Migration, Tactics of Bordering Chapel Hill: Duke University Press.

Stierl, M. (2018). A Fleet of Mediterranean Border Humanitarians Antipode 50(3): 704-724 
Tazzioli, M. (2015). The Desultory Politics of Mobility And The Humanitarian-Military Border In The Mediterranean. Mare Nostrum Beyond The Sea REMHU : Revista Interdisciplinar Da Mobilidade Humana 23(44), 61-82.

Tazzioli, M. (2017). Containment Through Mobility. Migrants' Spatial Disobediences and the Reshaping of Control Through the Hotspot System Journal of Ethnic and Migration Studies, online, doi:10.1080/1369183X.2017.1401514

Tsianos, V. and Karakayali, S. (2010). Transnational migration and the emergence of the European border regime: an ethnographic analysis European Journal of Social Theory 13(3), 373-87.

Vives, L. (2017). Unwanted Sea Migrants Across the EU Border: The Canary Islands Political Geography 61, 181-192.

Vrenna M. and Biondi Dal Monte F. (2011). L'emergenza "strutturale". Alcune riflessioni a margine degli sbarchi dei migranti provenienti dal Nord Africa Laboratorio WISS [Welfare Innovazione Servizi e Sviluppo] Scuola Superiore Sant'Anna di Pisa. Available at http://old.asgi.it/public/parser download/save/emergenza.strutturale.alcune.riflessioni.a.m argine.degli.sbarchi.dei.migranti.pdf (accessed 16 November 2017)

Walters, W. (2011). Foucault and frontiers: notes on the birth of the humanitarian border in U. Brockling, B. Krasmann, T. Lemke (Eds.), Governmentality: Current issues and future challenges, Routledge, New York City, NY, USA, 138-164.

Williams, J. M. (2015). From humanitarian exceptionalism to contingent care: Care and enforcement at the humanitarian border Political Geography 47, 11-20.

Zaun N. (2015). Why EU asylum standards exceed the lowest common denominator: the role of regulatory expertise in EU decision-making Journal of European Public Policy 23(1), 136-154. 